\title{
Pattern of Recurrent Hepatitis C in Deceased vs Living Donor Liver Transplantation: An Egyptian Experience
}

\author{
Mai Ismail Mehrez, Afaf Ibrahim Farrag, Medhat Hassan El Sahhar, Shereen Shoukry Hunter, \\ Mohamed El Beshlawy, Dalia Omran, Magdi Amin El Serafy
}

\begin{abstract}
Introduction: Hepatitis C virus (HCV) is the leading cause for liver transplantation (LT) and viral recurrence.

Objective: Whether HCV recurrence occurs earlier and severer for living donor liver transplantation (LDLT) than for deceased donor liver transplantation (DDLT).

Design: We evaluated preoperative and postoperative clinical, laboratory, and histological outcomes of 180 patients with LT (65 DDLT and 115 LDLT) since 1998 till 2006. Patients diagnosed for recurrence histologically were treated by combination therapy of pegylated interferon (IFN) and ribavirin (RBV).

Results: The LDLT group was significantly younger. CTP score was insignificant, while MELD score was higher in LDLT than DDLT. The mean preoperative $(p=0.012)$ and postoperative HCV-RNA ( $p=0.027$ ) count was significantly lower in DDLT group than LDLT group. At onset of recurrence, laboratory parameters were not significantly different between two groups. Histologically, 59.57 and $41.89 \%$ patients with DDLT and LDLT, respectively, diagnosed to have recurrence $(p>0.05)$. Fibrosis and activity scores were significantly higher in the LDLT group $(p \leq 0.01)$ compared to DDLT group. The response to treatment was higher in DDLT group.
\end{abstract}

Conclusion: HCV recurrence rates and severity of reinfection remain lcomparable for living and deceased organs. However, LDLT significantly increase the risk and severity of $\mathrm{HCV}$ recurrence than DDLT.

Keywords: Living donor liver transplantation, Deceased donor liver transplantation, HCV recurrence, Interferon therapy.

How to cite this article: Mehrez MI, Farrag AI, EI Sahhar MH, Hunter SS, El Beshlawy M, Omran D, El Serafy MA. Pattern of Recurrent Hepatitis C in Deceased vs Living Donor Liver Transplantation: An Egyptian Experience. Euroasian J HepatoGastroenterol 2013;3(2):111-116.

Source of support: Nil

Conflict of interest: None

\section{INTRODUCTION}

End-stage liver disease secondary to chronic hepatitis $\mathrm{C}$ virus $(\mathrm{HCV})$ infection is the most common indication for liver transplantation (LT) worldwide. ${ }^{1,2}$ Over the last decade, living donor liver transplantation (LDLT) has been embraced as an alternative option to increase the availability of organs and address the needs of patients who cannot await deceased donor liver transplantation (DDLT). ${ }^{3}$

Unfortunately, HCV reinfection of the graft occurs universally, and is associated with an aggressive course in a proportion of patients, which leads to graft cirrhosis in 10 to
$30 \%$ of recipients within 3 to 5 years. ${ }^{4,5}$ This in turn results in clinical decompensation in a significant proportion of $\mathrm{HCV}$ recipients who have developed cirrhosis of the allograft, with $40 \%$ developing clinical decompensation at 1 year, and up to $60 \%$ will suffer a decompensation episode 3 years after the diagnosis of cirrhosis. This unfortunately significantly affects patient survival, with an estimated survival rate of less than $10 \%$ at 3 years. ${ }^{6-8}$

Early reports have indicated that recurrence of $\mathrm{HCV}$ infection in LDLT recipients had an earlier and more aggressive clinical course compared to recurrence in the DDLT recipient. ${ }^{9,10}$ This phenomenon had been attributed to rapid graft regeneration and inflammation accompanied by poor graft function in the early postoperative period. ${ }^{9,10}$ The clinical practice in many programs had been significantly modified by their initial experience. However, significant conflicting evidence had also surfaced. ${ }^{11-15}$

In the present study, we compared the pattern of recurrent hepatitis $\mathrm{C}$, including the possible risk factors, onset, severity and the efficacy of HCV treatment in DDLT versus LDLT recipients.

\section{MATERIALS AND METHODS}

This study was conducted in the period from January 1998 till January 2006. One hundred and eighty patients were included in the study. All patients suffered HCV-related end-stage liver disease or HCC complicating HCV-related cirrhosis. A total of 115 patients were subjected to LDLT in Dar Al Fouad Hospital, Cairo, Egypt, while 65 patients were subjected to DDLT in Leeds Hospital in England, Boukhom Hospital in Germany and Tianjin Hospital in China. Clinical, laboratory and imaging data were collected for all patients' pretransplantation. After transplantation, adverse events in the form of bouts of rejection, pulse steroid therapy, cytomegalovirus (CMV) infection, biliary complications and type of immunosuppression during this period were reported. Patients were then followed up from January 2006 till December 2008 in Police Hospital, Agouza.

The study variables included patient and donor demographics, pretransplant and post-transplant viral load, the results of synthetic liver function tests before and after living-donor liver transplant, histologic data. The laboratory data included levels of aspartate aminotransferase, alanine aminotransferase, total and direct bilirubin, serum 
albumin, and alkaline phosphatase, as well as prothrombin concentration, all of which were evaluated before transplant and daily after transplant during the first postsurgical month, then twice weekly until the end of the third postsurgical month, then monthly, and then on longer intervals thereafter. HCV RNA in serum was detected by PCR assay (Cobas Amplicor HCV test version 2.0; Roche Molecular system; lower limit of detection $50 \mathrm{IU} / \mathrm{ml}$ ) before transplant, 3 months after transplant, and then whenever there is clinical indication.

Most of the patients received tacrolimus as postoperative immunosuppressant (63.08\% in DDLT patients and 70.43\% in LDLT patients), while $18.46 \%$ of DDLT patients and $3 \%$ only among LDLT patients received sirolimus. Regarding cyclosporine, it was taken by $13.85 \%$ of DDLT patients and $26.09 \%$ of LDLT patients.

At first a liver biopsy was done according to protocol biopsy at 1, 3 and 12 months. After 2002, liver biopsies were performed if there were unexplained elevations in liver enzymes. The biopsy was performed with ultrasonographic guidance and a conventional automatic 16-gauge Tru-cut needle. The coagulation profile was determined before the biopsy to ensure the safety of the patient.

The histopathologic diagnosis for the recurrence of HCV infection was based on the pattern of inflammatory infiltrate and a histologic activity index (an 18-point scale). The stage of fibrosis was assessed with a 6-point scale according to the Ishak modification of the Knodell classification. ${ }^{11}$ Other possible diagnoses (particularly cellular rejection or druginduced liver injury) were excluded.

All patients positive for HCV RNA by real-time PCR and showed histological evidence of recurrent $\mathrm{HCV}$ infection They received IFN- $\alpha 2 \mathrm{a}(180 \mu \mathrm{g} /$ week $)$ or IFN- $\alpha 2 \mathrm{~b}(1.5 \mu \mathrm{g} /$ $\mathrm{kg} /$ week) + RBV (1.3-1.5 mg/kg/day) for 48 weeks. Therapy was started at least 1 year post-transplantation.

The patients had on-treatment complete blood count and liver function tests assessed weekly in the first 4 weeks, then every 2 or 4 weeks thereafter.

RBV dose was reduced if hemoglobin levels decreased below $10 \mathrm{gm} / \mathrm{dl}$ and discontinued if hemoglobin levels were $<8.5 \mathrm{gm} / \mathrm{dl}$ despite erythropoietin therapy. Erythropoietin was started in patients with hemoglobin levels below $9.5 \mathrm{gm} / \mathrm{dl}{ }^{16}$

PEG-IFN dose was reduced to two-thirds the dose per week for platelet counts between 50,000 and $65,000 / \mathrm{mm}^{3}$ and for leukocyte counts between 1,700 and $2,000 / \mathrm{mm}^{3}$ and halved for platelet counts less than $50,000 / \mathrm{mm}^{3}$ and for leukocyte counts less than $1,700 / \mathrm{mm}^{3}$. PEG-IFN was discontinued in cases of platelet counts $<25,000 / \mathrm{mm}^{3}$ or white blood cell counts $<1,000 / \mathrm{mm}^{3}{ }^{3}{ }^{16}$

Treatment was continued for a period of 48 weeks in responders. Response was defined as at least two log decrease of the initial viral load (as estimated by quantitative PCR of HCV RNA) at week 12 and no viremia at week $24 .{ }^{16}$

Follow-up PCR was done every 3 months during the first year, then twice yearly in the second year, then once in the third year to ensure sustained virological response or detect any recurrence. HCV RNA was measured also whenever, clinically indicated (persistently elevated or any increase in serum ALT during therapy).

\section{STATISTICAL ANALYSIS}

Patients' data was tabulated and processed using SPSS (15.0) statistical package for Windows XP. The following patients' data were compared: before transplantation, followup after transplantation, at time of diagnosis of recurrence. Quantitative variables were expressed by means and standard deviation, while qualitative data were expressed by frequency and percent. Qualitative variables were analyzed using Chi-square or Fisher's exact test when appropriate. Quantitative variables were analyzed using student's t-test or Friedman's test when appropriate. In all tests, p-value was significant when $<0.05$.

\section{RESULTS}

Demographic data of LDLT and DDLT recipients are presented in Table 1 .

The preoperative viral load was $373967.58 \pm 577388.37$ $\mathrm{IU} / \mathrm{ml}$ in DDLT group, compared with $1018282.44 \pm$ 2197587.20 IU/ml in LDLT group, the mean count was significantly lower in DDLT group $(\mathrm{t}=-1.887 ; \mathrm{p}=0.012)$, and $66.3 \%$ of LDLT group had significantly high viremia, in comparison with $36.9 \%$ in DDLT group $\left(\chi^{2}=9.176\right.$, p-value $=0.0102)$ (Graph 1).

The mean postoperative viral load was significantly higher in LDLT (760341.62 $\pm 871713.61 \mathrm{IU} / \mathrm{ml})$ compared to DDLT group $(484766.58 \pm 668721.41 \mathrm{IU} / \mathrm{ml})(\mathrm{t}=2.207$, $\mathrm{p}=0.027)$. More than half $(64.62 \%)$ of DDLT group had

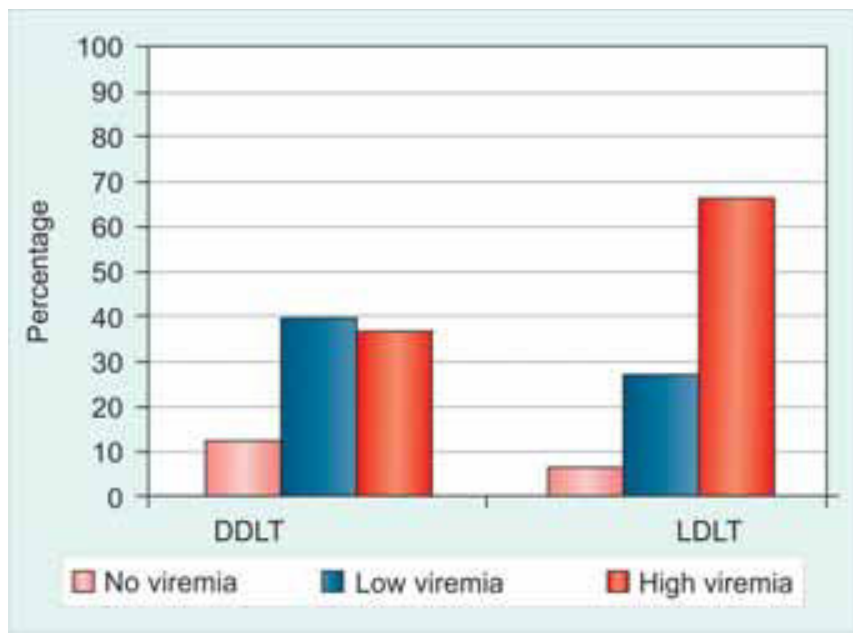

Graph 1: Preoperative viral load among both groups 
no viremia, while $18.46 \%$ had low viremia and $16.92 \%$ had high viremia, compared to $44.35,34.78$ and $20.87 \%$ in LDLT group respectively. This may be due to the use of preoperative interferon (IFN) therapy in some patients who underwent transplantation in Leeds Hospital (London). On comparison using Chi-square, it was found that the level of viremia was significantly higher in LDLT group $\left(\chi^{2}=8.097\right.$, $\mathrm{p}$-value $=0.017)$.

Recurrence of HCV was universal in terms of viremia. The time taken for clinical recurrence (indicated by evidence of viral replication shown via PCR after transplant, elevated levels of transaminases, and necroinflammatory changes) ranged from 3 to 38 months after transplantation among the DDLT group with a mean of $13.89 \pm 7.169$ months, while in LDLT group, it ranged from 1 to 39 months after transplantation with a mean of $10.94 \pm 9.491$ months. On comparing the time take for HCV recurrence between both groups, it was found to be statistically insignificant (t-test = 1.56 ; $\mathrm{p}$-value $=0.122)$. Clinical recurrence occurred in 28 patients following DDLT and 31 patients following LDLT. Various risk factors for clinical HCV recurrence after DDLT and LDLT were studied (Tables 2 and 3).

\begin{tabular}{|c|c|c|c|}
\hline & $D D L T(65)$ & $\operatorname{LDLT}(115)$ & Significance \\
\hline Male & $63(96.92 \%)$ & $109(94.78 \%)$ & NS \\
\hline Female & $2(3.08 \%)$ & $6(5.22 \%)$ & NS \\
\hline Age & $50.42 \pm 5.609$ & $47.32 \pm 10.475$ & 0.027 \\
\hline Diabetes & $40(61.54 \%)$ & $41(35.65 \%)$ & 0.000 \\
\hline Hypertension & $25(38.46 \%)$ & $74(64.35 \%)$ & 0.018 \\
\hline HBV coinfection & $3(4.6 \%)$ & $5(4.35 \%)$ & NS \\
\hline $\mathrm{HCC}$ & $16(24.62 \%)$ & $17(14.78 \%)$ & NS \\
\hline Child A & $32(48.9 \%)$ & $72(62.2 \%)$ & NS \\
\hline Child B & $14(21.3 \%)$ & $34(29.7 \%)$ & NS \\
\hline Child C & $19(29.8 \%)$ & $9(8.1 \%)$ & NS \\
\hline MELD score & $9.61 \pm 5.38$ & $11.43 \pm 3.73$ & 0.008 \\
\hline CTP score & $8.3 \pm 1.5$ & $8.9 \pm 1.3$ & NS \\
\hline
\end{tabular}

NS: not significant; HCC: hepatocellular carcinoma; MELD: model for end-stage liver disease; CTP score: Childs-Turcotte-Pugh score

\begin{tabular}{|c|c|c|c|}
\hline & $\begin{array}{c}\text { Recurrence } \\
(n=28)\end{array}$ & $\begin{array}{l}\text { No recurrence } \\
\quad(n=37)\end{array}$ & Significance \\
\hline CMV coinfection & $4(14.29 \%)$ & $1(2.7 \%)$ & NS \\
\hline Pulse steroids therapy & $13(46.4 \%)$ & $7(18.9 \%)$ & $S(0.034)$ \\
\hline Tacrolimus & $18(64.3 \%)$ & $23(62.2 \%)$ & NS \\
\hline Cyclosporine & $6(16.2 \%)$ & $2(7.1 \%)$ & NS \\
\hline Diabetes mellitus & $20(71.4 \%)$ & $20(54.1 \%)$ & NS \\
\hline \multicolumn{4}{|c|}{ Preoperative viral load (7 missing values) } \\
\hline & $\begin{array}{c}\text { Recurrence } \\
(n=24)\end{array}$ & $\begin{array}{l}\text { No recurrence } \\
\quad(n=34)\end{array}$ & Significance \\
\hline No viremia & $3(12.50 \%)$ & $5(14.71 \%)$ & \multirow[t]{3}{*}{ NS } \\
\hline Low viremia & $11(45.83 \%)$ & $15(44.12 \%)$ & \\
\hline High viremia & $10(41.67 \%)$ & $14(41.18 \%)$ & \\
\hline
\end{tabular}

S: significant; NS: not significant

\begin{tabular}{|c|c|c|c|}
\hline & $\begin{array}{l}\text { Recurrence } \\
(n=31)\end{array}$ & $\begin{array}{l}\text { No recurrence } \\
(n=84)\end{array}$ & $\begin{array}{l}\text { Significance } \\
p \text {-value }\end{array}$ \\
\hline CMV coinfection & $9(29 \%)$ & $6(7.14 \%)$ & 0.005 \\
\hline Pulse steroids therapy & $14(45.2 \%)$ & $26(31.0 \%)$ & NS \\
\hline Tacrolimus & $19(61.3 \%)$ & $59(70.2 \%)$ & NS \\
\hline Cyclosporine & $11(35.5 \%)$ & $21(25.0 \%)$ & NS \\
\hline Diabetes mellitus & $11(35.5 \%)$ & $29(34.5 \%)$ & NS \\
\hline \multicolumn{4}{|c|}{ Preoperative viral load (23 missing values) } \\
\hline & $\begin{array}{l}\text { Recurrence } \\
(n=31)\end{array}$ & $\begin{array}{l}\text { No recurrence } \\
(n=61)\end{array}$ & $p<0.05$ \\
\hline No viremia & $1(3.23 \%)$ & $5(5.95 \%)$ & \multirow[t]{3}{*}{ NS } \\
\hline Low viremia & $7(22.58 \%)$ & $18(21.43 \%)$ & \\
\hline High viremia & $23(74.19 \%)$ & $38(45.24 \%)$ & \\
\hline
\end{tabular}

NS: not significant 
Table 4: Grading and staging of HCV recurrence (Ishak score)

\begin{tabular}{l|llll} 
& $D D L T(n=28)$ & $\operatorname{LDLT}(n=31)$ & $p$-value \\
\hline Fibrosis score & $1.669 \pm 1.532$ & $2.227 \pm 1.159$ & $<0.01$ \\
Activity score & $4.846 \pm 2.483$ & $7.982 \pm 4.762$ & $<0.01$
\end{tabular}

As regard factors affecting HCV recurrence in DDLT group, the only significant factor was pulse steroid therapy $\left(\chi^{2}=4.46 ; p\right.$-value $\left.=0.034\right)$. CMV coinfection showed statistically significant difference $\left(\chi^{2}=7.773\right.$; $p$-value $=$ 0.005 ) in the LDLT group. In the DDLT group, nine patients showed low viremia, and 19 patients showed high viremia versus 11 and 20 patients respectively in the LDLT group.

On histopathological examination, the fibrosis score and the activity score were significantly higher in the LDLT group than the DDLT group $(\mathrm{t}=2.755$, $\mathrm{p}$-value $<0.01 ; \mathrm{t}=$ 3.121, p-value $<0.01$ respectively) (Table 4 ).

Among the patients diagnosed to have hepatitis $\mathrm{C}$ recurrence, $21 / 28(75 \%)$ and 17/31 (54.84\%) patients agreed to have treatment in DDLT and LDLT groups respectively. In the DDLT group, one (3.57\%) patient and in LDLT group, two $(6.45 \%)$ patients discontinued treatment due to severe side effects. On comparing end of treatment response among patients who received IFN, it was found that $14(70 \%)$ patients were responders in the DDLT group, compared to six (40\%) patients in the LDLT group, which was found statistically insignificant $\left(\chi^{2}=2.0449\right.$, p-value $\left.>0.05\right)$.

\section{DISCUSSION}

The Egyptian National Committee on Viral Hepatitis stated that $9.8 \%$ of the Egyptians are $\mathrm{HCV}$ infected, whereas other researchers claim that the figure is between 15 and 20\%. ${ }^{17}$

As DDLT being still not a valid option in Egypt, LDLT seemed to be the only choice to save many patients in desperate need for LT. ${ }^{18}$

The current study was conducted to compare the pattern of recurrent hepatitis $\mathrm{C}$, including the possible risk factors, lonset, severity and the efficacy of HCV treatment in DDLT versus LDLT candidates.

In our study, the incidence of hepatitis $\mathrm{C}$ recurrence was higher in DDLT (59.57\%) than LDLT (41.89\%) patients. This was lower than previous studies, ${ }^{7,10,12,19}$ where a histologically diagnosed recurrence of chronic hepatitis $\mathrm{C}$ occurred in 65 to $90 \%$ of HCV positive DDLT recipients during the first 2 years after surgery. In the current study, recurrence occurred within a time range from 3 to 38 months in DDLT group, while in LDLT group, it ranged from 1 to 39 months. This comes in agreement with the study done by Guo et al, ${ }^{20}$ where histological evidence of recurrent hepatitis occurred at 4 months and reached $90 \% 1$ year post-LT.

In the DDLT group, nine patients showed low viremia, and 19 patients showed high viremia compared to 11 and
20 patients respectively in the LDLT group. The higher level and activity of HCV may be due to rapid regeneration of the liver in LDLT group making the cells more prone to reinfection and their activity enhances the viral introduction and replication. ${ }^{21}$

Immunosuppression is considered a main factor in the severity of recurrent $\mathrm{HCV}$ infection, ${ }^{22,23}$ because of its effect on viral replication and its suppression of systemic immune responses, both of which can lead to accelerated hepatocellular damage and fibrosis.

In our study, tacrolimus and cyclosporine were not associated with $\mathrm{HCV}$ recurrence. Cyclosporine had antiviral properties in vitro and was associated with a significantly lower risk of recurrence of $\mathrm{HCV}^{24}$ and less fibrosis. ${ }^{25}$ However, no compelling data suggested that there was an advantage to using either tacrolimus or cyclosporine in clinical practice. ${ }^{26,27}$ In DDLT group, pulse steroid therapy was significantly related to HCV recurrence $(p=0.034)$. This might be due to the increased use of pulse steroid to treat rejection which was encountered more in this group (possibly due to prolonged ischemia time). Our results were similar to previous studies. ${ }^{20}$ In contrast, Yosry et al ${ }^{28}$ suggested that immunosuppressive therapy and pulse steroid therapy were not associated with $\mathrm{HCV}$ recurrence.

Due to the fact that CMV has immunomodulating properties, it was presumed that reactivation of CMV could accelerate $\mathrm{HCV}$ pathogenesis in critically ill patients. ${ }^{29} \mathrm{This}$ came in agreement with our results that CMV coinfection was significantly correlated with HCV recurrence in LDLT group. On the contrary, a recent study showed that CMV coinfection was not associated with $\mathrm{HCV}$ recurrence. ${ }^{30}$ Moreover, Nebbia et $\mathrm{al}^{31}$ proved in his study that $\mathrm{HCV}$ infected patients with CMV DNAemia were not at increased risk of liver fibrosis at 1 year post-transplantation.

Severity of recurrence was assessed by fibrosis and activity scores in liver biopsy, where the LDLT group showed significantly higher grade of fibrosis $(2.227 \pm$ $1.159)$ and inflammation $(7.982 \pm 4.762)$ than DDLT group $(1.669 \pm 1.532$ and $4.846 \pm 2.483$ respectively) $(\mathrm{p}<0.001)$. This might be due to higher cellular activity in the LDLT group, reflecting the need of the hepatocytes to regenerate so they are more prone to be reinfected by $\mathrm{HCV}^{9}, 21,32 \mathrm{On}$ the contrary, other studies did not identify LDLT as a risk factor for more intense HCV recurrence. ${ }^{11,12,14,15,20}$

These discrepancies in the outcomes in different centers could be clarified according to Wiesner et $\mathrm{al}^{33}$ explanation which was centered on the definition of recurrent hepatitis. He strongly encouraged the wide application of the consensus criteria formulated by the International Liver Transplantation Society. Clarity in definition of recurrent $\mathrm{HCV}$, which should join histological with biochemical 
parameters, is of utmost importance until less invasive diagnostic parameters are developed.

In the current study, treatment with pegylated IFN and RBV was started in $75 \%$ of DDLT patients and $54.84 \%$ of LDLT patients. Patients who did not receive therapy deliberately decided to postpone it and to be followed up.

Three patients (one in DDLT group and two in LDLT group) dropped out during therapy due to serious side effects. This was similar to the results of the study conducted by Iacob et $\mathrm{al}^{34}$ where 11 to $37 \%$ of patients discontinued the therapy.

Among those who completed the therapy, $70 \%$ of DDLT group and $40 \%$ of LDLT group achieved end of treatment response (ETR) after 48 weeks of therapy. These results were in agreement with other studies. ${ }^{35}$

From this study, we could conclude that the incidence of hepatitis $\mathrm{C}$ recurrence is higher in DDLT but the severity is more in LDLT. Pulse steroid therapy and CMV were related to recurrence in DDLT and LDLT respectively. While diabetes mellitus, preoperative viral load and the use of tacrolimus or cyclosporine as immunosuppressant did not affect recurrence.

\section{CONTRIBUTORSHIP}

All the authors have carried out the study, participated in the design of the study and data collection, performed the statistical analysis and wrote the manuscript. All authors have read and approved the final manuscript.

\section{REFERENCES}

1. United Network for Organ Sharing. Available from: http://www. unos.org. Accessed: May 2008.

2. Adam R, McMaster P, O'Grady JG, Castaing D, Klempnauer JL, Jamieson N, Neuhaus P, Lerut J, Salizzoni M, Pollard S, et al. Evolution of liver transplantation in Europe: report of the European Liver Transplant Registry. Liver Transpl 2003 Dec;9(12):1231-1243.

3. Humar A. Donor and recipient outcomes after adult living donor liver transplantation. Liver Transpl 2003 Oct;9 (Suppl 10C):S42-S44.

4. Berenguer M, Ferrell L, Watson J, Prieto M, Kim M, Rayón M, Córdoba J, Herola A, Ascher N, Mir J, et al. HCV-related fibrosis progression following liver transplantation: increase in recent years. J Hepatol 2000 Apr;32(4):673-684.

5. Berenguer $\mathrm{M}$. What determines the natural history of recurrent hepatitis C after liver transplantation? J Hepatol 2005 Apr;42(4):448-456.

6. Berenguer M, Prieto M, Rayon JM, Mora J, Pastor M, Ortiz V, Carrasco D, San Juan F, Burgueño MD, Mir J, et al. Natural history of clinically compensated hepatitis $\mathrm{C}$ virus-related graft cirrhosis after liver transplantation. Hepatology 2000 Oct;32(4 Pt 1):852-858.

7. Gane EJ, Portmann BC, Naoumov NV, Smith HM, Underhill JA, Donaldson PT, Maertens G, Williams R. Long-term outcome of hepatitis $\mathrm{C}$ infection after liver transplantation. N Engl J Med 1996 Mar;334:815-820.
8. Berenguer M. Natural history of recurrent hepatitis C. Liver Transpl 2002 Oct;8(10 Suppl 1):S14-S18.

9. Gaglio PJ, Malireddy S, Levitt BS, Lapointe-Rudow D, Lefkowitch J, Kinkhabwala M, Russo MW, Emond JC, Brown RS Jr. Increased risk of cholestatic hepatitis $\mathrm{C}$ in recipients of grafts from living versus cadaveric liver donors. Liver Transpl 2003 Oct; $9(10): 1028-1035$.

10. Garcia-Retortillo M, Forns X, Llovet JM, Navasa M, Feliu A, Massaguer A, Bruguera M, Fuster J, Garcia-Valdecasas JC, Rimola A. Hepatitis C recurrence is more severe after living donor compared to cadaveric liver transplantation. Hepatology 2004 Sep;40(3):699-707.

11. Shiffman ML, Stravitz RT, Contos MJ, Mills AS, Sterling RK, Luketic VA, Sanyal AJ, Cotterell A, Maluf D, Posner MP, et al. Histologic recurrence of chronic hepatitis $\mathrm{C}$ virus in patients after living donor and deceased donor liver transplantation. Liver Transpl 2004 Oct;10(10):1248-1255.

12. Russo MW, Galanko J, Beavers K, Fried MW, Shrestha R. Patient and graft survival in hepatitis $\mathrm{C}$ recipients after adult living donor liver transplantation in the United States. Liver Transpl 2004 Mar;10(3):340-346.

13. Rodriguez-Luna H, Balan V, Sharma P, Byrne T, Mulligan D, Rakela J, Vargas HE. Hepatitis C virus infection with hepatocellular carcinoma: not a controversial indication for liver transplantation. Transplantation 2004 Aug;78(4):580-583.

14. Bozorgzadeh A, Jain A, Ryan C, Ornt D, Zand M, Mantry P, Lansing K, Orloff M. Impact of hepatitis $C$ viral infection in primary cadaveric liver allograft versus primary living donor allograft in 100 consecutive liver transplant recipients receiving tacrolimus. Transplantation 2004 Apr;77(7):1066-1070.

15. Humar A, Horn K, Kalis A, Glessing B, Payne WD, Lake J. Living donor and split-liver transplants in hepatitis $\mathrm{C}$ recipients: Does liver regeneration increase the risk for recurrence? Am J Transplant $2005 \mathrm{Feb}$;5(2):399-405.

16. Matsuura K, Tanaka Y, Hasegawa I, Ohno T, Tokuda H, Kurbanov F, Sugauchi F, Nojiri S, Joh T, Mizokami M. Abbott RealTime hepatitis $\mathrm{C}$ virus (HCV) and Roche Cobas AmpliPrep/Cobas TaqMan HCV assays for prediction of sustained virological response to pegylated interferon and ribavirin in chronic hepatitis C patients. J Clin Microbiol 2009 Feb;47(2):385-389.

17. El-Zanaty F, Way A. Egypt demographic and health survey 2008. Cairo, Egypt: Ministry of Health, El-Zanaty and Associates, and Macro International; 2009. p. 1-300.

18. El-Gazzaz GH, El-Elemi AH. Liver transplantation in Egypt from West to East. Transplant Res Risk Manag 2010 Apr:2:41-46.

19. Gane E. The natural history and outcome of liver transplantation in hepatitis C virus-infected recipients. Liver Transpl 2003 Nov;9(11):S28-S34.

20. Guo L, Orrego M, Rodriguez-Luna H, Balan V, Byrne T, Chopra K, Douglas DD, Harrison E, Moss A, Reddy KS, et al. Living donor liver transplantation for hepatitis C-related cirrhosis: no difference in histological recurrence when compared to deceased donor liver transplantation recipients. Liver Transpl 2006 Apr;12(4):560-565.

21. Eguchi S, Takatsuki M, Yamanouchi K, Kamohara Y, Tajima Y, Kanematsu T. Regeneration of graft livers and limited contribution of extrahepatic cells after partial liver transplantation in humans. Dig Dis Sci 2010 March;55(3):820-825.

22. Charlton M. Liver biopsy, viral kinetics, and the impact of viremia on severity of hepatitis $\mathrm{C}$ virus recurrence. Liver Transpl 2003 Nov;9(11):S58-S62. 
23. Watt K, Veldt B, Charlton M. A practical guide to the management of $\mathrm{HCV}$ infection following liver transplantation. Am J Transplant 2009 Aug;9(8):1707-1713.

24. Herrero JI, de la Peña A, Quiroga J, Sangro B, García N, Sola I, Cienfuegos JA, Civeira MP, Prieto J. Risk factors for recurrence of hepatitis C after liver transplantation. Liver Transpl Surg 1998 Jul;4(4):265-270.

25. Oton E, Barcena R, Castillo M, Barreales M, Blesa C, MorenoPlanas JM, Barrios C, Garrido A, Cuervas V. Hepatitis C virus recurrence after liver transplantation: influence of immunosuppressive regimens on viral load and liver histology. Transplant Proc 2006 Oct;38(8):2499-2501.

26. Berenguer M, Palau A, Fernandez A, Benlloch S, Aguilera V, Prieto M, Rayón JM, Berenguer J. Efficacy, predictors of response, and potential risks associated with antiviral therapy in liver transplant recipients with recurrent hepatitis C. Liver Transpl 2006 Jul;12(7):1067-1076

27. Hilgard P, Kahraman A, Lehmann N, Seltmann C, Beckebaum S, Ross RS, Baba HA, Malago M, Broelsch CE, Gerken G. Cyclosporine versus tacrolimus in patients with $\mathrm{HCV}$ infection after liver transplantation: effects on virus replication and recurrent hepatitis. World J Gastroenterol 2006 Feb;12(5):697702.

28. Yosry A, Abdel-Rahman M, Esmat G, El-Serafy M, Omar A, Doss W, Zayed N, Said M, Ismail T, Hosny A, et al. Recurrence of hepatitis $\mathrm{C}$ virus (genotype 4) infection after living-donor liver transplant in Egyptian patients. Exp Clin Transplant 2009 Sep;7(3):157-163.

29. Razonable RR, Burak KW, van Cruijsen H, Brown RA, Charlton MR, Smith TF, Espy MJ, Kremers W, Wilson JA, Groettum $\mathrm{C}$, et al. The pathogenesis of hepatitis $\mathrm{C}$ virus is influenced by cytomegalovirus. Clin Infect Dis 2002 Oct;35(8):974-981.

30. Tryphonopoulos P, Weppler D, Morris MI, Russo C, Nishida S, Levi DM, Moon J, Tekin A, Selvaggi G, Island E, et al. The effect of donor-recipient cytomegalovirus serology on adult liver transplantation: a single center experience. Transplantation 2011 Nov;92(9):1051-1057.

31. Nebbia G, Mattes FM, Sabin CA, Samonakis D, Rolando N, Burroughs AK, Emery VC. Differential effects of prednisolone and azathioprine on the development of human cytomegalovirus replication post liver transplantation. Transplantation 2007 Sep;84(5):605-610.

32. Forman LM, Trotter JF, Emond J. Living donor liver transplantation and hepatitis C. Liver Transpl 2004 Mar; 10(3):347-348.

33. Wiesner R, Edwards E, Freeman R, Harper A, Kim R, Kamath P, Kremers W, Lake J, Howard T, Merion RM, et al. Model for end-stage liver disease (MELD) and allocation of donor livers. Gastroenterology 2003 Jan;124(1):91-96.

34. Iacob S, Gheorghe L, Hrehoret D, Becheanu G, Herlea V, Popescu I. Pegylated interferon $\alpha-2 \mathrm{a}$ and ribavirin combination therapy in HCV liver transplant recipients. Experience of 7 cases. J Gastrointestin Liver Dis 2008 Jun;17(2):165-172.

35. Dumortier J, Scoazec JY, Chevallier P, Boillot O. Treatment of recurrent hepatitis $\mathrm{C}$ after liver transplantation: a pilot study of peginterferon alfa-2b and ribavirin combination. J Hepatol 2004 Apr;40(4):669-674.

\section{ABOUT THE AUTHORS}

\section{Mai Ismail Mehrez (Corresponding Author)}

Department of Internal Medicine, National Hepatology and Tropical Medicine Research Institute, 10 Kasr Al Aini Street, Cairo, Egypt Phone: 01001702809,0233471936,e-mail: madopaki@yahoo.com

\section{Afaf Ibrahim Farrag}

Faculty of Medicine, Department of Endemic Medicine and Hepatogastroenterology, Cairo University, Cairo, Egypt

\section{Medhat Hassan EI Sahhar}

Department of Hepatogastroenterology and Endoscopy, Police Authority Hospital, Cairo, Egypt

\section{Shereen Shoukry Hunter}

Faculty of Medicine, Department of Endemic Medicine and Hepatogastroenterology, Cairo University, Cairo, Egypt

\section{Mohamed El Beshlawy}

Faculty of Medicine, Department of Endemic Medicine and Hepatogastroenterology, Cairo University, Cairo, Egypt

\section{Dalia Omran}

Faculty of Medicine, Department of Endemic Medicine and Hepatogastroenterology, Cairo University, Cairo, Egypt

\section{Magdi Amin El Serafy}

Faculty of Medicine, Department of Endemic Medicine and Hepatogastroenterology, Cairo University, Cairo, Egypt 